\title{
Bringing War Home: Violent Crime, Police Killings and the Overmilitarization of the US Police
}

\author{
Federico Masera*
}

November 8, 2016

Job Market Paper

\begin{abstract}
The withdrawal from the Afghan and Iraqi wars has led to the arrival of vast quantities of military equipment to the US. Much of this equipment, now unused by the military, has been redistributed to police departments via a program called 1033. In this paper, I study the causal effect on criminal activity and police behavior of the militarization of the police through this program. I do so by taking into account that military equipment is stored in various disposition centers. Police departments do not pay for the cost of these items but must cover all transportation costs. I then use the distance to a disposition center and the timing of the US withdrawal from the wars in an instrumental variable setting. Estimates show that military equipment reduces violent crime and is responsible for $60 \%$ of the rapid drop observed since 2007. More than one third of this effect is caused by the displacement of violent crime to neighboring areas. Because police departments do not consider this externality when making militarization decisions, they overmilitarize. Finally, I show that police militarization increases the number of people killed by the police. Estimates imply that all the recent increases in police killings are due to police militarization.
\end{abstract}

*Universidad Carlos III de Madrid - Email: fmasera@eco.uc3m.es - Address: Universidad Carlos III de Madrid, Economics Department, C/ Madrid 126, 28903 Getafe (Madrid), España 


\section{Introduction}

Almost $70 \%$ of the US population lives under the jurisdiction of a local enforcement agency that is equipped with military weapons. At least 200 operations are deployed by the police each day with these items [Kraska (2007); Coyne and Hall-blanco (2016)]. Although the US police has been partly militarized for many decades, this phenomenon has accelerated quickly with the distribution of over one billion dollars in military equipment during the last few years ${ }^{1}$. These rapid changes in the way public security is provided are not confined to the US. As terrorist threats have escalated recently, many police forces in Europe have increased their use of military equipment ${ }^{2}$. In the developing world, police departments have been heavily militarized for many years, and in some cases the army is directly used in order to fight crime $^{3}$.

Although the use of military equipment by police has become widespread around the world, very little is known on its effects. In the US, police militarization has become highly debated following the use of military equipment by police during Ferguson's infamous riots. The debate continued in recent years after President Obama's executive order restricted the use of military equipment by the police. After the killings in July 2016 of five officers in Dallas and three in Baton Rouge, changes to police militarization are being discussed again in the US Congress ${ }^{4}$. On one side of the argument are police departments, sheriff's offices and pro-police movements who defend police militarization as a needed tool for effective

\footnotetext{
${ }^{1}$ These estimates are calculated using only data from program 1033 the main federal program that allows local enforcement agencies to acquire military weapons in the US. Alternatively, local enforcement agencies could buy military weapons using their own finances or Department of Homeland Security grants. Unfortunately comprehensive data on this type of acquisition of military weapons is not available.

${ }^{2}$ Operation Sentinelle was launched in France after Charlie Hebdo massacre of January 2015 with 10'000 military forces sent across France. In 2016 both Belgian and Dutch police forces were allowed to carry heavy military guns when protecting high-risk sites.

${ }^{3}$ The militarization of public security is particularly present in Latin America. Examples can be found with Mexico where President Calderon send 50,000 soldiers to fight drug-trafficking criminals, PMOP initiative in Honduras against street gangs and Venezuelan President Maduro's decision in 2013 of sending 3,000 soldiers to combat crime in Caracas.

${ }^{4}$ For reference: The Executive Order 13688 reformed the use of military equipment by the police in January 2015. As of September 2016 Amendment 1208 is conferenced with the Senate with the objective of reversing the executive order.
} 
and safe law enforcement. On the other side of the debate are civil liberties and activist groups who see police militarization as a violation of constitutional rights and fear that it will increase police brutality.

In this paper, I contribute to this discussion by providing causal estimates on the effects of police militarization on criminal activity and police behavior. I do so by studying "Program 1033", the main program that transfers military equipment to police departments in the US. When the army began withdrawing from the Afghan and Iraqi wars at the end of 2009, military equipment returned to the US and was then distributed to police departments through this program. In order to estimate the causal effect of this military equipment, I use the fact that, when returning from war, military equipment is available at various disposition centers across the US. I then show that police departments close to these disposition centers are especially prone to be militarized. This was particularly true after the start of the withdrawals from the Iraqi and Afghan wars, when military weapons became massively available. There are two main reasons for this behavior. First, the only cost that police departments have to incur when acquiring military equipment is the transportation cost from the disposition center. Secondly, every police department must appoint an officer to personally inspect the military items before this is requested. Inspections can be cheaper and more frequent if the police department is located near a disposition center. I then use the timing of the US withdrawal from the wars and the closeness to a disposition center to construct an instrumental variable to estimate the causal impact of the militarization of the US police. In the estimation procedure I take particular care of the fact that disposition centers are not randomly located in the US but are a subsample of military bases. I do so by controlling for the closeness to a military base, where a military base may or may not be a disposition center, interacted with year dummies. Because of this the only cross-sectional variation I use comes from the fact that some military bases were selected as disposition centers in 1997, when Program 1033 was created. I then show how before the withdrawal from the wars observables characteristics of places close to military bases are similar between 
those that were selected as disposition centers and those who where not.

With this instrumental variable setting I show that police militarization can reduce violent crimes. For each dollar per capita of military equipment in the possession of a police department, violent crime is reduced by 7\%. Estimates suggest that Program 1033 has prevented almost 1.8 million violent crimes since its inception in 1997. Most of the prevented crimes are concentrated in the last few years, when militarization has become particularly widespread. Conservative cost estimates predict that 78 billion US dollars have been prevented in costs to the victims of these violent crimes and the US justice system. Additionally, I show how police militarization is an important factor in the recent acceleration in the drop of violent crime in the US. Since 2007, violent crimes have decreased by an impressive $18 \%$. Estimates suggest that more than $60 \%$ of this drop is due to police militarization. Finally, I show that at least one third of the effect that militarization has on violent crime is through the displacement of criminal activity to neighboring areas. This displacement effects have important implications for the optimality of the decision to militarize of each police department. When police departments decide on their level of militarization, they need not take into account these negative externalities on neighboring areas. Because of this, police departments are overmilitarized.

I then focus my analysis on one of the most discussed outcomes related to police militarization: police killings. The number of people killed by the police has rapidly increased, rising from 400 in the year 2000 to more than 1000 in recent years. Instrumental variable estimates show that the militarization of the police increases police killings. I show that every 1.6 million dollars spent in military equipment generates an extra police killing per year. My estimates imply that all the recent increases in police killings are due to police militarization through Program 1033. In total, 2200 individuals have been killed due to the militarization of the police caused by Program 1033. Using conservative estimates of the statistical value of life, the total cost in life lost amounts to more than 17 billion US $\$$.

This paper is related to the investigation of the causes and effects of police militariza- 
tion. Balko (2014) provides a complete analysis of the history of police militarization and a description of the policies and practices that led to a level of militarization unprecedented in the history of the US. ACLU (2014) reports the results of sending public records requests to 260 enforcement agencies. The study shows how enforcement agencies have become highly militarized due to the use of Program 1033 and that the major use of military equipment is in drug raids. Closer my paper, Bove and Gavrilova (2015) investigates the effects of Program 1033 on crime and concludes that militarized counties experienced a reduction in street crime level. First, I improve on the identification the causal effects of militarization. Instead of using average military aid by the federal government to predict the cross-sectional variation police militarization I use some predetermined characteristics, namely the geographical distribution of US military bases and disposition centers. This let me be sure that my results are not driven by unobserved factors that the determine the propensity of receiving military equipment. Second, I use more detailed data on police militarization at the law enforcement agency level instead of at the county level. This allows me to study displacement effects and ultimately show the existence of overmilitarization in the US police. I can do that by focusing my study on local law enforcement agencies instead of on the full set of enforcement forces in the US. The main advantage of this approach is that local law enforcement agencies have non-overlapping jurisdictions. Because of this, any increase in militarization in one jurisdiction should have no direct effect on another jurisdiction. Additionally, with this new dataset, I avoid the problem of overrepresenting policing resources in a county that includes the state capital. This problem arises because most state and federal agencies are normally located in the state capital, but their jurisdiction is broader than a county. Finally, I study the effects of militarization on a new outcome: police killings. This phenomenon has lately entered public discussion in relation police militarization and I show that this is an important dimension to consider when evaluating the overall impact of Program 1033. My work is related to Dell (2015), which studies the effects of Mexico's policy against drug-trafficking that involved, among other things, heavy use of military equipment. Estimates show that 
this policy actually increased drug-related violence. In my paper, I isolate the effects on crime of having military equipment instead of the more diversified policy studied in Dell (2015). Furthermore, I can provide elasticities of military equipment on crime, as I directly observe how much police departments are militarized.

More broadly, my paper is related to the literature that studies the effects of policing on crime. The most recent literature review can be found in Chalfin and Mccrary (2015). Most related to my analysis are studies that exploit quasi-experiments that attempt to uncover the elasticities of crime to changes in policing. The main threat for credible identification in this literature is the endogeneity of policing. The main concern is that, when police departments expect increases in crime, they boost their policing efforts, thus confounding any potential negative effects of policing on crime. The first paper attempted to address this endogeneity problem is Levitt (1997), which uses the timing of mayoral and gubernatorial elections as an instrument from changes in policing. Di Tella and Schargrodsky (2004) and Draca, Machin and Witt (2011) use terrorist attacks in Buenos Aires and London and the subsequent deployment of police in specific areas of these cities as an exogenous shock to policing to study the effects on crime. Other papers, such as Machin and Marie (2011) and Evans and Owens (2007), use the allocation of additional resources in certain cities in the UK and the US to examine the effectiveness of policing on crime reduction. This literature shows that an increase in policing is generally effective at reducing crime. My main contribution to this literature is the study of a specific change in policing: the use of military weapons by the police. Furthermore, I am the first to provide causal evidence on the determinants of police killings. Additionally, my study uncovers some geographical displacement effects that are in line with classical theories of rational criminals, but for which there has previously been very little empirical evidence. Finally, it is important to note that my estimates are identified from a completely new source of variation. In particular, an differently from the other papers in the literature, I exploit an event that occurred many years before the activation of the treatment to identify the causal effect of policing. In fact, the cross-sectional variation I use 
is given by a combination of the position of military bases in the US that were mostly built during the WW2, and the selection of storage facilities that were selected in 1997.

The structure of the paper is as follows: In section 2 I will present the data that is used and how program 1033 works. Section 3 presents the econometric strategy, the main results and discuss the validity of the identifying assumption. In Section 4 I explore the potential mechanisms that could generate these results. Section 5 studies the effect of militarization on police safety and police killings. Finally, in section 6, I present concluding remarks.

\section{The 1033 Program and Data}

The defense and logistics agency (DLA) is an US combat logistics agency that provides a wide range of logistics, acquisition and technical services to the army, marine corps, navy, airforce and other federal agencies. Of particular interest to my analysis are the services they provide under the reutilization, transfers and donation section. This section of the DLA redistributes military equipment that the department of defense (DoD) declares as excess to its needs. These items are then turned-in to one of DLA's disposition centers that serve as a storage facility. Once these items are received they enter a one week accumulation period, where the items are inspected and cataloged. Then DoD exclusive screening period starts where only DoD agencies can search for military equipment. After that a 21 days screening period starts where police departments and other enforcement agencies may search for excess military equipment. In order to participate in the screening police departments must first join the 1033 program and the application has to be approved by the 1033 program state coordinator and the DLA. After the approval the police department appoints an official to visit their local DLA disposition site. If interested in any item the police department places the request trough the DLA website. The item must have a justification and be approved by the state coordinator and the DLA. The police department that receives an approval for property transfer must cover all transportation costs but doesn't pay for the cost of the item. 
The DLA in their dataset provides information on the date, the name of the item, the market value and the receiving enforcement agency for all the excess military equipment transferred through the 1033 program $^{5}$. Since the inception of this program in 1998 more than 8000 enforcement agencies have enrolled in this program. Since 2010 there have been a spike in the use of the 1033 program. As shown in Figure 1 the total value of the items transferred to police departments by the 1033 program has passed from a few millions every year to almost 600 millions dollars in 2014. Furthermore as reported by the American Civil Liberties Union (ACLU (2014)) in this period span no police department has ever returned the military equipment back to the DLA. With this information I can build the value of the stock of military equipment available to all police departments at any point in time by summing up the value in dollars of the the military equipment received up to that point by the police department ${ }^{6}$. The military equipment transferred through program 1033 is extremely varied with almost 7800 type of items. Military vehicles make up almost $55 \%$ of the total value that has been transferred. The most common vehicles are mine resistant vehicles and armored trucks. Around $40 \%$ of the value is composed by military weapons and equipment. Assault rifles, night vision equipment, camouflage and body armor are some of the most common items. The remaining $5 \%$ is comprised of non-tactical items that include computers, electricity generators, recreational and gymnastic equipment.

For crime data I use the Uniform Crime Reporting (UCR) statistics produced by the FBI. This dataset have been published yearly since 1958 and collects data on violent crime and property crime. I then link this data to the militarization data described before by matching the agencies names.

\footnotetext{
${ }^{5}$ Throughout the paper the analysis is confined to the lowest level of law enforcement in the US. These local enforcement agencies include police department, sheriff offices

${ }^{6}$ In the baseline specification for creating the stock of military equipment I sum up the value of military equipment acquired up to that moment without taking into account any depreciation.
} 


\section{Econometric Framework}

\subsection{Identification Strategy}

First I study the direct effect of militarization of the police department on violent crime rate. The first outcome will violent crimes as these types of crime are orders of magnitude more costly to society with respect to non-violent crimes as property crimes or possession of illicit drugs. Formally I would like to estimate the following equation.

$$
v c_{i, t}=\alpha_{i}+\alpha_{t}+\beta_{1} \operatorname{mil}_{i, t}+\beta X_{i, t}+\epsilon_{i, t}
$$

Where $i$ identifies the police department, $t$ the year, $v c_{i t}$ is the rate of violent crime per 1000 inhabitants and $m i l_{i, t}$ is the value of the stock of military equipment per capita. A problem of this analysis, that is common to other studies that trying to find how some characteristic of policing affects crime, is the clear presence of an endogeneity problem. First of all, this happens because of a reverse causality problem where police department in which crime rate will increase demand more military equipment. Secondly, there are many potential unobservable characteristics of a police jurisdiction that determine contemporaneously crime and the demand for military equipment. These include the demographic characteristics of the local population, local economic activity, the political situation and many other. The structure of 1033 program let's me uncover the causal effect of the militarization of the police of crime $\left(\beta_{1}\right)$ by exploiting some exogenous cross-sectional and time variation in the use of the 1033 program.

First of all, I exploit the fact that the excess military equipment available to redistribute via the 1033 program is particularly high when an US military missions ends. In the time frame of interest the main US military operation is the "Operation Enduring Freedom" that started in October 2001 with the invasion of Afghanistan and then expanded in March 2003 in Iraq. As shown in Figure 1 the military involvement in Iraq and Afghanistan steadily increased with a first peak reached in February of 2005 with 181500 soldiers on the ground (161200 in Iraq and 20300 in Afghanistan). After that the level of boots on the ground was 
maintained for a few year until the surge of US forces called in Iraq by then US president George W. Bush in January of 2007. The number of military equipment and troops increased rapidly again until August of 2009 when 240500 soldiers were on the ground in Iraq and Afghanistan. From the end of 2009 the US started a slow withdrawal from Iraq that then began a few years later in Afghanistan in early 2012. As shown in Figure 1 the return of troops in late 2009 coincides with the start of the exponential increase in military equipment distributed by the program 1033 to police departments. The timing of the withdrawal from the war allows me to predict the time variation of aggregate military equipment distributed in the US.

For solving the endogeneity problem I need a way of predicting also the large crosssectional variation observed in the data. In $200950 \%$ of the US population was living under the protection of a militarized police department. This percentage increased to $65 \%$ percent in 2014. Even between the police departments that are militarized there is a huge variation. In 2009 the median militarized police department had 13 cents of a dollar per capita in military equipment with only $15 \%$ of them having more than 1 dollar per capita. This crosssectional distribution rapidly changed after the start of the withdrawal from the war. In 2014 the median militarization is of 71 cents with $43 \%$ having more than 1 dollar per capita. For capturing this cross-sectional variation of the militarization of the police I will exploit the fact that police departments close to DLA disposition centers should demand more military equipment from the 1033 program. The main reason for this is that the costs of acquiring items are increasing with the distance to the disposition center. First because, when a police department acquires a military item through the 1033 program the only direct cost it has is the special transportation that has to be arranged from the DLA disposition center to the police department. Secondly, before the acquisition of an item, the agent appointed by the police department has to go to the disposition center to screen the item of interest and inspect its conditions. Is important to remember that most of the items transferred via the 1033 program have been already used in the Iraqi and Afghan wars and their conditions 
may vary. Potentially these items may require some repairs and all repair costs have to be sustained by the police department. The screening process is then essential for police departments to not incur in unforeseen repair costs. Additionally, the process of screening is rapid lasting by law a maximum of 21 days. Being able to quickly go to inspect the military equipment of interest is of fundamental importance for a police department. Because of these reasons police departments specially close to the disposition centers are prone to ask more and receive more items from the 1033 program. Figure 2 shows the location of all police departments and the 69 DLA disposition centers that participate in the 1033 program in continental US. As shown in the map disposition center are spread out throughout the US with the median distance of a police department from the closest disposition center of $106 \mathrm{Km}$.

I then combine these two sources of variation (one in time and the other cross-sectional) to try to predict exogenously the militarization of all police departments. This is done with the objective of then using this first stage estimate in a instrumental variable setting to estimate the causal effect of militarization on crime as shown in equation (1). The general specification of the first stage is the following:

$$
\operatorname{mil}_{i, t}=\alpha_{i}+\alpha_{t}+\beta_{1} \text { eqp }_{t} * \text { closeness }(\text { disp. center })_{i}+\beta X_{i, t}+\epsilon_{i, t}
$$

Where $e q p_{t}$ measures the availability of excess military equipment as proxied by the difference from the peak of the boots on the ground in Iraq and Afghanistan that was reached in 2009 and the subsequent years. This measure $e q p_{t}$ has been then normalized to 1 in 2014. Formally eqp is defined below, where boots $t_{t}$ is the number of boots on the ground that the US military in Iraq and Afghanistan as shown in Figure 1:

$$
e q p_{t}= \begin{cases}0 & \text { if } t<2010 \\ \frac{\text { boot }_{2009}-\text { bootst }_{t}}{\text { boots }_{2009}-\text { boots }_{2013}} & \text { if } t \geq 2010\end{cases}
$$

The variable closeness(disp.center $)_{i}$ can be calculated in many way using the information shown in Figure 2 of the position of the police department and the DLA disposition centers. 
Some natural candidates for the function "closeness" are the distance to the closest disposition center or a dummy indicating if a disposition center can be found in a certain radius from the police department or counting the number of disposition center around a police department.

The main identification assumption behind this strategy is that changes in the violent crime between years of high availability and low availability of equipment are not different between close and far away places from a disposition center other than through the military equipment received by these places. The main threat to the identification strategy comes from the fact that disposition centers are just military bases that has been selected by the National Defense Authorization Act of 1997 as DLA disposition centers for the 1033 program. If police departments around military bases differ, in unobservables that determine changes in violent crime rates, with respect to places far away from military bases this will invalidate the identification strategy. This is a reasonable concern as places close to a military base differ on many characteristics (demographics, labor market structure, political preferences, etc...) and potentially many are unobservable. For this reason in all my specification I will control for the fact of being close to a military base (where a military base may or may not be a DLA disposition center). The military bases that are used as a control are the ones that are currently still open and that could have potentially been selected as DLA disposition centers in 1997. This doesn't include military hospitals, military training centers and joint airports. There are 237 military bases that comply with these characteristics of which as said before 69 were selected as DLA disposition centers.

Formally I will estimate the following 2 stages in an instrumental variable setting:

$$
\begin{gathered}
\text { First Stage: } \\
\operatorname{mil}_{i, t}=\alpha_{i}+\alpha_{t}+\beta_{1} \text { eqp }_{t} * \text { closeness }(\text { disp. center })_{i}+\beta_{2, t} \text { year }_{t} * \text { closeness }(\text { mil. base })_{i}+\epsilon_{i, t} \\
\underline{\text { Second Stage: } v c_{i, t}=\delta_{i}+\delta_{t}+\theta_{1} \text { mil }_{i, t}+\theta_{2, t} \text { year }_{t} * \text { closeness }(\text { mil. base })_{i}+\gamma_{i, t}}
\end{gathered}
$$

With the following specification the only excluded instrument is $e p_{t} *$ closeness(disp.center $)_{i}$. Because of this the only cross-sectional variation I use comes from the fact that some military 
bases have been selected to be disposition centers in 1997. Is important to notice that this specification discounts the fact that places disposition centers are also military bases and because of this places close to disposition have potentially different trends in violent crime. Furthermore I let the closeness to a military base have a different influence year by year. Because of this I don't impose that the unobservable factors that happen close to a military base happen at the same time as the withdrawal of troops from Iraq and Afghanistan.

\subsection{First Stage}

As described before there are potentially many ways of combining the information in Figure 2 to create a proper measure of closeness. As a baseline throughout the paper I define a place to be close to a DLA disposition center is if it is located at less than $20 \mathrm{Km}$ (air distance) from it. Throughout the paper I will show how results are robust to many other definitions that can be used for closeness to a disposition center. The decision is useful for two reason: First of all is one of the measures of closeness that has the best predicting power. Secondly being a dummy makes let me borrow a lot of language and tools from the treatment and control literature. In particular with this definition is very simple the to define which of the police department are treated and which are not.

As a first visual exploratory analysis in Figure 3 I compare the time-series of the value of the stock of military equipment of police department close to a disposition center (I will call this police departments "treated" throughout the rest paper) to places close to a military base that is not a disposition center (denoted as "placebo treated"). First of all, we can notice how as in Figure 1 that from 2010 onward there is a huge increase in the militarization of police departments. Treated police departments are always more militarized than the placebo treated ones. This difference is just of a few cents per capita until 2009. As soon as the withdrawal from the war in Iraq and Afghanistan happened in late 2009 the difference between these 2 groups of police departments diverged. In 2014 treated police departments had more than 1 dollar per capita of difference in the level of militarization. That is around 
a $65 \%$ more than the placebo treated police departments.

More formally in Table 1 are reported the estimates for $\beta_{1}$ for the first stage previously described. All regression results are estimated with sample from 2007 to 2014. Column 1 shows the baseline specification that defines a police department as close if situated at less than $20 \mathrm{~km}$ from a DLA disposition center. The other columns show the robustness the first stage results to other definitions of closeness. In column 2 a police department is defined as close if situated at less than $40 \mathrm{~km}$ from a DLA disposition center. In column $3 \mathrm{I}$ use the distance in $\mathrm{Km}$ and in column 4 the logarithmic distance in $\mathrm{Km}$ from the closest disposition centers. In column 5 and 6 I use the number of disposition centers in a radius of $50 \mathrm{Km}$ and $100 \mathrm{Km}$.

Table 1 shows formally what could be already noted in Figure 3. Police departments close to disposition centers increase more than far away ones their level of militarization after 2009. This is true using different ways of calculating the closeness to DLA disposition centers.

\subsection{Baseline Results}

With this identification strategy I'm now able to estimate the causal effect of the militarization of the police on the violent crime rate. The baseline regression results are shown

in Table 2. OLS results shown in columns (1) and (2) are consistent with reverse causality where police departments that predict to have increases in violent crimes tend to militarize more. Columns (3) and (4) present the preferred specifications. Both show how militarization per capita reduces the violent crime rate. In particular every dollar per capita in military equipment decreases violent crime by 1.4 per 1000 inhabitant or as shown in column (4) by around 6.4 percent. Finally column (5) shows with the reduced form estimates that places close to a disposition experienced a drop in the violent crime rate after 2009 higher than other places in the US.

For interpreting the marginal effects found in Table 2 notice that in 2014 the average 
militarization of a police department in the US is of 3.2 dollars per capita. This amount of money would be enough for a police department of 100000 inhabitants to afford a 10 man fully armed military squad ${ }^{7}$. A police department of these dimensions would have around 3.3 violent crimes a day. The estimates of Table 2 imply that without militarization the daily crimes would be around 4.5 or 4.1 depending if I use the linear of the logarithmic estimation respectively. As shown in this example the militarization of the police has a huge direct effect on the reduction of violent crime.

\subsection{Plausibility of Identification Strategy}

The previous results hinge on the identifying assumption that violent crime rates between years of high availability and low availability of military equipment are not different between police departments treated and placebo treated other than through the military equipment received by these places. Another way of looking at this assumption is that in 1997 when the program was created the selection made over which are going to be the military bases that are used as disposition centers was not biased towards places that after 2009 will have a higher drop in violent crime.

It seems reasonable to assume that the selection of disposition centers was not actively biased towards places that will experience a disproportionately high drop in violent crime 12 years later. First, because if any we would expect the bias to be in the opposite direction. Military bases could be selected as disposition centers if they are predicted to experience an increase in violent crime around them. If this is the case I could interpret my results as a lower bound of the effect of the militarization on crime and the real effect is potentially even higher. Secondly, is not feasible to predict so many years ahead violent crime trends. This is specially true in the US where the crime has moved spatially a lot in the last two

\footnotetext{
${ }^{7}$ Expenses for fully equipping a military squad highly depend on the type and quality of items. The example of the 10 man fully armed squad I use includes 1 armored truck, 1 explosive disposal equipment, 2 night-vision googles and 2 thermal sights. Added to this a set of 10 assault rifles, sights and body armor. Depending of the quality of these items it may cost around 320000 dollars of 3.2 per capita for this hypothetical city of 100000 population police department.
} 
decades because of the intensification of the war of drugs, the arrival of new kind of drugs like Oxycontin and the decline of some prosperous industrial cities. Still it could be the case that the places selected as disposition centers where selected because of some other reason that ended being relevant in causing different trends in crime in 2009.

To explore if this is in fact the case in Table 3 I first provide evidence that police departments treated and placebo treated are similar in many predetermined observables that are potentially related to crime. Column 2 and 3 show that treated and placebo treated do not differ in any substantial way. Is also important to notice how a treated police department and ones that not close to a military base (denominated with "Other" in the Table) are instead substantially different. These police departments tend to be smaller in population and bigger in area and have lower crime rates with respect to the treated ones. This observation further validates the identification strategy that is used throughout the paper that controls for the distance to a military base as an included instrument.

As further evidence in favor of the identification assumption I now explore the validity of the parallel trends assumption. For my estimation procedure this assumption states that trends of violent crime would have been parallel between treated and placebo treated police departments in a hypothetical world where both of them would have not been militarized. Even if this counterfactual world is not directly observable in the data I here provide evidence that is consistent with the parallel trends assumption. First in Figure 4 I explore visually if there is a basis to believe that violent crime rates are parallel before 2010, where both treated and placebo treated police departments are practically not militarized. As observed in Figure 4 for the decade previous to the withdrawal from the wars in Afghanistan and Iraq Violent crime rates where slowly decreasing of around $4 \%$ in these 10 years. At a first visual inspection time series of violent crimes before 2009 seem parallel between places treated and placebo treated. A more formal test of this important characteristic of the data is left for later in this section. After 2009 police departments in both groups experienced a substantial decrease in violent crime. Police departments placebo treated decreased crime by $11 \%$ in 
those 5 years while police departments treated experience a decrease of $19 \%$. The main argument of my paper is that this differential decrease in violent crime experienced after 2009 is due to the higher militarization of places close to disposition centers with respect to places close to a military base that is not a disposition center. The differential treatment of the police departments in these 2 groups has been previously visually explored in Figure 3.

As further evidence of the parallel trends assumption in Table 4 are shown the differences between 2006 and 2009 of various criminal outcomes. These differences are computed for the treated, the placebo treated and other police departments as defined before. Of the 14 outcomes I report in Table 4 only 2 have marginally different trends between police departments treated and placebo treated. Importantly, violent crimes trends between treated and placebo treated police departments do not have statistically different trends. This is an encouraging result as it means that in general there where no particular differences between these 2 groups and any change in trends after 2009 could be plausibly attributed to program 1033.

As final evidence of the validity of the identification strategy I perform an event study analysis. The intention here is to formally test the intuition displayed in Figure 4 by comparing in a flexible way if there are any differences between places treated and placebo treated. Then looking if these differences changed after start of the withdrawal of the Iraqi and Afghan war. For checking this I estimate the following regression:

$v c_{i, t}=\sigma_{i}+\sigma_{t}+\sigma_{1, t}$ year $_{t} * 1(\text { disp.center }<20 K m)_{i}+\sigma_{2, t}$ year $_{t} * 1\left(\text { mil. base }_{2}<20 K m\right)_{i}+\epsilon_{i, t}$

The sample includes all police departments yearly data from 2000 to 2014. The comparison year has been set to be 2009 the last year before the start of the withdrawal from the wars. The estimates of $\sigma_{1, t}$ are shown in Figure 5. Before 2010, there is no statistical difference between places close and far away from disposition centers. As soon as troops, and more importantly military equipment, returned to the US violent crime around disposition centers starts decreasing faster than in any other place. 


\subsection{Robustness}

In Table $5 \mathrm{I}$ show how the results are robust to the choice of the instrument. In all the specifications the effects of militarization per capita on violent crime are negative. The effects of an extra dollar per capita of militarization varies from -0.8 to a maximum of -1.7 . Is important to notice that results may vary because the complier subpopulation for each instrument is different. In particular the decision to use or not program 1033 because you are in the $20 \mathrm{Km}$ or $40 \mathrm{Km}$ radius from a disposition center is potentially more binding for small/medium disposition centers, as for them also small differences in transportation cost may be very important for the decision of using the 1033 program. This may influence the estimated parameter if we have that the effect of militarization on crime is different for small and large departments. Is also important to notice that there seem to be some clear nonlinearities in the use of the program 1033 with respect to distance. Because of this reason column (3) that includes distance from a disposition center linearly is the one the estimation with less predictive power.

Secondly for showing the robustness of the main results I perform the main regression this time including in the sample only places that are less than $20 \mathrm{Km}$ from a military base. This regression directly compares only places close to disposition centers and military bases that are not disposition centers without using any information from other police departments. From Table 6 we can observe how all the main results are practically the same both in the direction and the size. This is in part is to be expected as the variation the main regression is using is the different trends in crime post-2009 between places close to a DLA disposition center and other military bases.

As further robustness check I perform the main specification with two alternative way of defining the set of relevant military bases. First of all I include as military bases all military bases in the US even if they are now closed. This add up to 389 military bases as in the main specification only 69 of them are actually DLA disposition centers. In my second specification I include all military bases that are now open even if they couldn't 
have been selected in 1997 as DLA disposition centers because of the type of activities that are performed there. These include military hospitals, military bases devoted completely to training or military airports that are joint with civilian ones. In total there are 290 military bases in this specification. In Table 7 results are shown. The main results all hold and the magnitudes are very similar to the main specification.

Finally, in the following econometric exercises I provide further evidence that there is indeed something special that is affecting crime after 2009 in places close to a disposition center that is not happening in any other place in the US. Specially is not happening in other comparable places around military bases that are not disposition centers. For doing that I choose at random 69 military bases and assign them as "fake" disposition centers. I them run the following reduced form regression:

$v c_{i, t}=\sigma_{i}+\sigma_{t}+\sigma_{1} e q p_{t} * 1(\text { FAKEdisp.center }<20 K m)_{i}+\sigma_{2, t}$ year ${ }_{t} * 1\left(\text { mil.base }_{2}<20 K m\right)_{i}+\epsilon_{i, t}$

I repeat this procedure 1000 times and plot in Figure 6 the distribution of the $\sigma_{1}$ with the thick red line indicating the same reduced form parameter with the "real" 69 disposition centers. As shown in Figure 6 in general there is no effect on crime of being close to a fake disposition center. Comparing results with the parameter of the actual reduced form as shown by the thick red line in Figure 6 no combination of military bases assigned as fake disposition centers can replicate the huge negative effects on violent crime of being close to the real disposition centers. The claim of the paper is that the difference between places close to disposition centers and any other place in the US is the preferential access to the program 1033 and ultimately the militarization of these police departments.

As a last check of the robustness of the main results in Table 8 are shown the estimates of a set of IV regressions that do not include in the sample large police departments and another set of regression not weighted by population. The first purpose of this regression is to see how much the results are driven by big police departments. Additionally this regression will inform us on the complier population and if there are any heterogeneous effects along the population dimension. First thing to notice is that in all the regressions the main results 
are maintained: Militarization reduces violent crime. These effects are substantially less important with respect to the main results where all police departments are included but the F-statistics of the first stage are bigger. Looking first at the size of the coefficient we can say that militarization is more effective when carried out by big police departments. This is in line with the idea that for effectively using this equipment specialized training is needed. This specialized training and the creation of a full-time militarized squad is only feasible by big police departments that can afford for this training and have at their disposal a bigger amount of officers. Secondly F-statistics increase as big police departments are eliminated from the estimating subsample. This is very informative over which are the compliers of the instruments used in the estimation. What the change of the F-statistic suggests is that big police departments are not part of the complier population. This is again in line with the idea that big police departments do not have as many budgetary constraints when deciding if they should get some military equipment. Because of this, in the context of my estimation strategy, they can be seen as always-takers. In other words, big police departments can afford the transportation cost of military equipment even if located at more that $20 \mathrm{Km}$.

\section{Mechanisms}

\subsection{Displacement Effects}

In line with criminals as rational actors, criminals may react to increases in militarization in a jurisdiction by moving there criminal activities to neighboring ones. Is crucial to understand the presence and size of these displacement effects especially for the evaluation of policing policies. First of all, the effectiveness of hot spot policing, that mandates to concentrate policing efforts in places where crime is pervasive, is conditional on how important displacement effects are. Furthermore, more specifically to program 1033, displacements effects may induce the overmilitarization of police. This is due to the fact that militarization decision through the 1033 program are made at the police department level while, if displacement 
effects exists, spillovers will be suffered by neighboring police departments as well. Because of this negative externalities not internalized by the police department when making the militarization decision we would observe that in equilibrium police departments are militarized more than optimally.

In this section I'll investigate the presence of displacement effects with the following econometric framework:

$$
v c_{i, t}=\alpha_{i}+\alpha_{t}+\beta_{1} m i l_{i, t}+\beta_{2} W_{i} \mathbf{m i l}_{\mathbf{t}}+\beta X_{i, t}+\epsilon_{i, t}
$$

Where $W_{i}$ is a weighting matrix that select the range and intensity of the displacement effects and $\mathbf{m i l}_{\mathbf{t}}$ is a vector of militarization per capita of all police departments at time $t$. When evaluating displacement effects as a baseline regression I study spillovers confined by the commuting zone where the police department is located. In average each commuting zone has 76 police departments. So in this specification $W_{i} \mathbf{m i l} \mathbf{t}_{\mathbf{t}}$ is the average militarization of police departments in the commuting zone of police department $i$. The analysis of displacement effects adds another endogeneity problem as in equation (2) also $W_{i} \mathbf{m i l}_{\mathbf{t}}$ is potentially endogenous because of reverse causality and omitted variable bias. First, neighboring police departments may decide to increase their militarization because of a general trend in the increase in violence of a certain commuting zone leading to a reverse causality problem. Secondly there are potentially many unobservables that are common to a commuting zone that cause at the same time militarization of a police department and violent crime changes. Because of this I will also use as an instrument the average closeness to a disposition center in the commuting zone.

As shown in Table 9 displacement effects are present and seem to be relatively important. For each dollar per capita spend in a police department commuting zone the violent crime rate increases by 0.5 per 1000 inhabitants. In column (4) where the outcome of interest is the logarithm of the violent crime rate we observe and increase in violent crime of 2.6 percent. This amounts to around one third of the direct effect that the militarization of police has on violent crime. 
For interpreting the marginal effects found in Table 9 I return to the example of a police department of 100000 inhabitants that is able to afford a 10 man fully armed military squad. As discussed in the previous chapter a police department of this dimensions would have around 3.3 violent crimes a day in 2014. The estimates of Table 9 imply that without militarization the daily crimes would be around 4.2 and 3.8 depending if I use the linear of the logarithmic estimation respectively. This shows how even if the effect of militarization on violent crime are still sizable the effects as not as large as when the estimation was carried not taking into account displacement effects.

For getting a better sense of the magnitude of the results in Figure 7 I plot in blue the violent crime rate (per 1000 population) from the year 2000 and in red the predicted violent crime rate if there was no militarization of the police. The logarithmic regression shown in Column (4) of Table 9 is used a for predicting this counterfactual scenario. First thing to notice is that since 2007 there has be an acceleration in the secular drop in violent crime in the US. From 2007 to 2014 violent crime has decrease by an astonishing 18.3\%. What the counterfactual analysis suggests is that the drop would have been much more contained without program 1033. Violent crime would have dropped only $7.2 \%$. In other words the militarization of the US police trough the 1033 program contributed to $61 \%$ of the drop in violent crime experienced between 2007 and 2014.

Another way of quantifying the results is looking at the total effect of 1033 program since it has been implemented in 1997. The estimates shown in Column (4) of Table 9 predict that this program has prevented 1.8 million violent crimes since it's inception. Most of these prevented violent crimes are in recent years. Trying to put a monetary value of to the prevented cost to society produced by the reduction in crime of the 1033 program is not an easy task. First of all, the cost produced by violent crime depends by the type of crime. Secondly, even when a crime is know different methods disagree on cost produced by each crime. An excellent review of the literature is given by McCollister, French and Fang (2010). Using less costly violent crime (that is $42310 \$$ for a robbery) as the most conservative 
estimate program 1033 has prevented is 76 Billion US\$ in costs.

\subsection{Incapacitation or Deterrence}

The mechanisms by which more policing may lead to a reduction in crime can be very broadly divided into two categories: incapacitation and deterrence. The first effect is just a mechanical one, where more policing leads to more arrests, less criminals circulating on the streets and consequently less crimes. Deterrence instead arises when rational criminals observe the change in policing and decide as a response to change their amount of criminal activity. From a policy maker perspective is important to understand which of the two mechanisms has caused the drop in crimes. If the main mechanism at play is incapacitation this would create two additional costs for the society: First, incarceration is expensive and this especially true for violent crimes that generally require a long incarceration period. Secondly, the productive possibilities of the individual incarcerated are diminished (both during and after the incarceration). Instead deterrence is a much more desirable mechanism as it doesn't involve any cost to the judicial system and potentially moves economic activities out of the illegal sector.

For detecting which mechanism is at play is important to notice that, if the effect was all due to incapacitation, arrests would increase due to the militarization of the police. Instead, if the mechanism was deterrence, we should observe a decrease in the arrests after a police department gets militarized. As a first way of investigating which mechanisms is at play in Table 10 I look at the effects of the militarization of the police on arrests of violent criminals. Results seem to indicate that arrests have decreased but not in a statistical important way. The effects of the militarization of the police on arrests are always smaller than with respect to the effects it has on crime. This seems to suggest that the mechanisms at play are some combination between incapacitation and deterrence.

For a better understanding of how these two force shape the dynamics of arrests and crimes I study the following econometric framework. 


$$
\begin{gathered}
\text { Arrest }_{i, t}=\beta_{i}+\beta_{t}+\beta_{1, t} \text { year }_{t} * 1(\text { disp. center }<20 K m)_{i}+\beta_{2, t} \text { year }_{t} * 1(\text { mil. base }< \\
20 K m)_{i}+\epsilon_{i, t}
\end{gathered}
$$

Where Arrests $_{i, t}$ is the number of violent crimes cleared by arrest per 1000 inhabitants. I then compare these estimates to the one already reported in Figure 5 that studies the same dynamics for violent crime. Figure 5 show in red the estimates for $\beta_{1}$ for comparison purposes the figures also reports the same estimates for violent crimes in blue. Arrest drop is much less pronounced. Secondly, also the timing of this drop is different. As seen before violent crimes decrease immediately after the withdrawal from Iraq and Afghanistan in late 2009. Instead for arrests the seem to start dropping two years later. This is perfectly in line with a situation where when a police department starts being militarized crimes drop for a combination of incapacitation and deterrence. Because of this arrests remain constant. After a few year deterrence seem to be the main force driving the continuous drop in crimes. This can be explained by a situation where criminals learn about the militarization of the police by observing the arrival of this equipment and this learning process takes time to reach all potential criminals.

\subsection{Substituting or Adding Resources}

In order to evaluate the cost-effectiveness of program 1033 and understand what mechanisms drive the observed decrease in crime is important to study if other police department resources change as it become more militarized. For doing so I'll use employee data of police departments across the US. The number of employees could decrease, as now with military equipment the amount of work requires less policemen. If this was the case the previously shown estimates where actually underestimating the effects of program 1033 by just examining crime data, as it also would have the effect of saving resources. Conversely, the number of employees could also increase because with military weapons the police departments may decide also to hire specialized trained officers to use this equipment effectively. Indeed the use of this specially trained officers is part of the recommendations given by the White House 
in their report studying program 1033. Table 12 shows the instrumental variable estimates of the effect of militarization on different types of employees in a police department. Program 1033 seems to have no effect. This fact is reassuring for the causal interpretation of all the previous results. In particular, when a police department gets militarized given that the number of policemen doesn't change we can assign all the effect in reduction of crime to the arrival of military equipment.

\section{$5 \quad$ Police Safety and Police Killings}

One of the main arguments for the militarization of the police is that may improve the safety of police officers. This has become a problem especially in the last decades when criminals, have become armed with more powerful weapons putting in danger the lives of policemen [Police Executive Research Forum (2010)]. Additionally, in the last years there have been some violent acts directly targeted at the police forces that have captured the attention of the public. Just in July of 2016 five officers were killed in Dallas and three in Baton Rouge in two attacks directly aimed at killing policemen. These and other previous incidents led to the creation of a nation wide movement called "blue lives matter" for bringing attention to the numerous deaths in the police forces in the US. One of the potential benefit of the militarization of the police, that the organization "blue lives matter" puts forward, is that the police may do their job without risking of being injured or killed. The reason is that policemen could better protected and are able to detect the presence of potential threats easily with military equipment. On the other side, policemen may be more prone to be involved in more aggressive and dangerous operations now that they are militarized leading ultimately to a higher risk for policemen. Using official FBI data I study the effect of the militarization of the police on deaths and injuries on the job of policemen. A first look at the data shows how each year in the US between 40 to 50 policemen are killed and more than 40000 are assaulted. Table 12 reports the effect of militarization on the safety of the police. 
Results show how none of these variables is statistically affected by the militarization of the police. All estimates are positives meaning that potentially the militarization of the police made police officers even more unsafe.

Another important outcome that is often discussed with the rise of militarization of the police the use of deadly force by the police while in the line of duty. Unfortunately data on these killing are either incomplete or come from unofficial sources. One official statistic is provided by the FBI supplementary homicides report that documents an increase in the last years of police killings, reaching a peak in 2013 of 435 . Unfortunately agencies are not required to communicate to the FBI about police killings and so any aggregate information is severely unreported. More relevant to the estimation, this underreporting may be not random as agencies may decide to not submit the report exactly in years when these type of homicides are high. The quality of the data of the FBI data and other official sources, like the BoJ Arrest-Related Deaths, has been shown to be very poor [Banks et al. (2015a)]. A recent report commissioned by the BoJ [Banks et al. (2015b)] shows how at best these official sources have captured around half of all police killings with considerable variability in quality between states.

Because of this unreliability of the official data many non-governmental organizations have tried to create alternative data sources of homicides committed by the police. Even the head of the FBI, James Comey, admitted that unofficial data are the best source of information about police killings ${ }^{8}$. One of the main datasets is the one produced by "fatalencounters.org" a project that collects and aggregates data from various media news sources and public records. This dataset reports that police killings had rapidly increased in the last years passing from around 660 in 2010 to a peak of 1120 in 2013. These numbers reported by fatalencounters are substantially higher that the one by the FBI but are in line with other efforts of other non-governmental organizations. The newspaper The Guardian has estimated 1146 people were killed by the police in 2015. Similar numbers have been

\footnotetext{
${ }^{8}$ Declaration by James Comey the 7th of October 2015 at the Summit on Violent Crime Reduction in Washington, DC
} 
estimated by the websites "killedbythepolice.net" and "fivethirtyeight.com". Using the "fatalencounters.org" data, Table 12 shows the effects of the militarization of the police on the number of individuals killed by the police (over 10000 inhabitants). Estimates show that militarization of the police increase police killings. Each dollar per capita more of military equipment increases the number of killing by the police by 0.08 per 100000 inhabitants. This estimate implies that the militarization of the police can explain all of the recent increases in police killings. Around 2200 individuals have been killed due to the militarization of the police caused by the program 1033. Using conservative estimates of the statistical value of life in the US the total cost in life lost amounts to more than 17 billion US $\$$. Another important collateral cost of the increase in the number of police killings is that that police as an institution may lose value and trust in the citizens. From Gallup polls we can see how the confidence in the police is the lowest since 1993 with only 52\% of Americans trusting the police. Finally studying the causes of police killings may also give us some insights in an even more prevailing phenomenon that is people injured by the police. As shown by [Miller et al., 2016] in 201255400 people where injured by the police. While no systematic dataset is available for studying the causal effect of militarization of police related injuries is reasonable to assume that as police killings have increased due to militarization so have injuries.

When looking at police killings in the US a very important dimension often discussed by the general public is race. Most famously, the activist movement "black live matter", campaigns against what they see as systematic racism and violence by the police against black people. The previously cited Gallup polls on the trust that citizens have on the police show a marked racial gap in this statistic. While $58 \%$ of whites trusts the police only $29 \%$ of blacks have the same feelings. Famously the DoJ has investigated the Ferguson police department after the protests for the shooting of a black man called Micheal Brown. The investigation indeed found a pattern of racial bias towards the black community. Exploring

\footnotetext{
${ }^{9}$ Estimates used by government agencies to asses the value of a life vary from 7.9 million dollars use by the Food and Drug Administration up to 9.4 million dollars used by the Transportation Department
} 
if this patterns is present in the US as a whole or is isolated to a few police departments is particularly hard because, as discussed previously, is very difficult to have detailed data on police killings. Unfortunately sometimes even when basic data on a incident is available the race of the victim is not reported. For example, in the data provided by "fatalencounters", $36 \%$ of the times race is not reported. Even with this partial information we can observe how blacks are statistically overrepresented in the victims of police killings. Even if blacks represent $12 \%$ of the population of the US $31 \%$ of the police killings are suffered by blacks. These percentages are in line with other forms of overrepresentation of blacks in the arrested population $28 \%$ and incarcerated population $38 \%{ }^{10}$. This statistical overrepresentation even if worrisome is not proof of racism by the police. What these numbers may just reflect some underlying phenomenon that is correlated both with crime and being black. With my analysis I can study the possibility of racism in the use of deadly force by the police from another perspective, by looking at the causal effect of the militarization on police killings only of black people. The intuition behind this type of analysis is that the militarization of the police gives more opportunities for the use of the deadly force by the police. If the police is racist they could disproportionately use force against blacks and when the police gets militarized this could lead to an increase especially of police killings of black individuals. As shown in column (4) of Table 12 militarization doesn't influence in a statistically significant way police killings of black people. So what the militarization seem to be doing is to mitigate the overrepresentation of black people in police killings. Again is important to state that this doesn't imply that the police are not racist towards black individuals. Because similarly as what it was discussed before there may be some other underlying characteristics that influence the reaction of police killings to the militarization that are correlated with the race status. Still this result provides some new evidence concerning the important relation between the use of deadly force by the police and race.

\footnotetext{
${ }^{10}$ Arrests data from the FBI 2013: 9.014 Millions arrests of which 2.549 to Blacks or African American. Incarcerated population in state prisons for more than 1 year in 2013 from BJS: 1.325 Million people of which 0.497 Blacks.
} 


\section{Conclusion}

This paper studies the effects of the militarization of the police through program 1033 on police behavior and criminal activity. I first document how program 1033 is a major factor in the recent drop in violent crime, being responsible for $60 \%$ of the rapid drop in violent crime observed since 2007. The empirical evidence suggests that it does so both by deterring criminal activity and by displacing crime to neighboring areas. This evidence is in line with a model of rational criminal that observe the level of militarization of the police and decide where and how much crime to commit. I then show how militarization of the police increases police killings and program 1033 is responsible for practically all of the recent increase. In total 2200 people have been killed by the police due to the militarization.

Since the unrest that happened in Ferguson in 2014, that brought the militarization of the police in the political debate, program 1033 has been under scrutiny. A congressional investigation started immediately after the riots and in January 2015 program 1033 was reformed banning the reutilization of some types of military equipment. After the five police officers were killed in a Dallas shooting that happened in July 2016 another change of the program is in talks in the Congress in order to reverse the reform of January 2015. This paper provides some important insights for guiding the policy makers discussion. First these elasticities imply that for preventing 818 violent crimes the militarization of the police will generate one extra police killing. Secondly, police militarization seems not to make police officers safer. Finally, the highly decentralized nature of the program leads to an

overmilitarization of the US police. This is the result of police officers not taking into account the externalities that are created to neighboring areas when acquiring new military equipment. Any policy that wants to deal with the overmilitarization of the police will have to reform who decides how much to be militarized. 


\section{References}

ACLU. 2014. "The Excessive Militarization of American Policing." June.

Balko, Radley. 2014. Rise of the Warrior Cop: The Militarization of America's Police Forces. PublicAffairs.

Banks, Duren, Caroline Blanton, Lance Couzens, and Devon Cribb. 2015a. "ArrestRelated Deaths Program: Data Quality Profile."

Banks, Duren, Lance Couzens, Caroline Blanton, and Devon Cribb. 2015b. “ArrestRelated Deaths Program Assessment." March.

Bove, Vincenzo, and Evelina Gavrilova. 2015. "Policeman on the Frontline or a Soldier ? The Effect of Police Militarization on Crime."

Chalfin, Aaron, and Justin Mccrary. 2015. "Criminal Deterrence : A Review of the Literature."

Coyne, Christopher J, and Abigail R Hall-blanco. 2016. "Foreign Intervention , Police Militarization, and the Impact on Minority Groups." Peace Review.

Dell, Melissa. 2015. "Trafficking Networks and the Mexican Drug War." American Economic Review, 105(November): 1-58.

Di Tella, Rafael, and Ernesto Schargrodsky. 2004. "Do police reduce crime? Estimates using the allocation of police forces after a terrorist attack." American Economic Review, 94(1): 115-133.

Draca, Mirko, Stephen Machin, and Robert Witt. 2011. "Panic on the streets of London: Police, crime, and the july 2005 terror attacks." American Economic Review, 101(5): 2157-2181. 
Evans, William N., and Emily G. Owens. 2007. "COPS and crime." Journal of Public Economics, 91(1-2): 181-201.

Kraska, Peter. 2007. "Militarization and Policing - Its Relevance to 21st Century Police." Policing.

Levitt, Steven. 1997. "Do electoral cycles in police hiring really help us estimate the effect of police on crime?" The American Economic Review, 87(3): 270-290.

Machin, Stephen, and Olivier Marie. 2011. "Crime and police resources: The street crime initiative." Journal of the European Economic Association, 9(4): 678-701.

McCollister, Kathryn E., Michael T. French, and Hai Fang. 2010. "The cost of crime to society: New crime-specific estimates for policy and program evaluation." Drug and Alcohol Dependence, 108(1-2): 98-109.

Miller, Ted, Bruce Lawrence, Nancy Carlson, Delia Hendriw, Sean Randall, Ian Rockett, and Rebecca Spicer. 2016. "Perils of police action: a cautionary tale from US data sets." Injury Prevention.

Police Executive Research Forum. 2010. "Guns and Crime: Breaking New Ground By Focusing on the Local Impact." 


\section{Appendix}

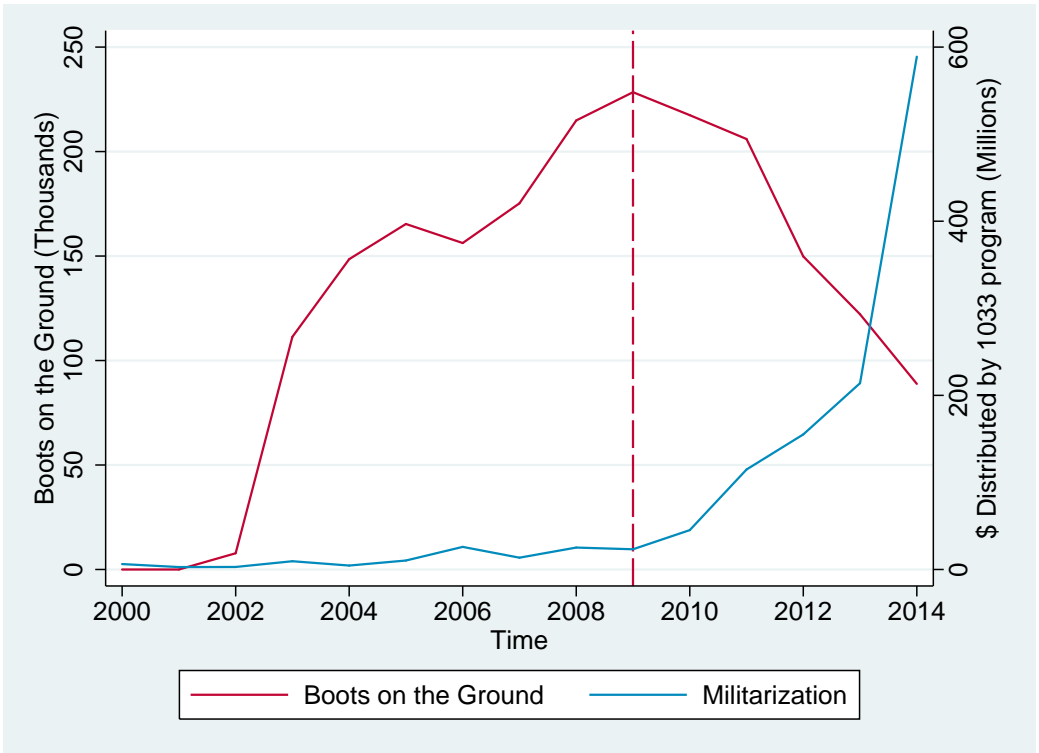

Figure 1: Value of the items transferred by the 1033 program to police departments (Blue) and Yearly average boots on the ground in Afghanistan and Iraq (Red). To the right of the dotted line (after 2009) starts the inflow of item from the withdrawal from the wars

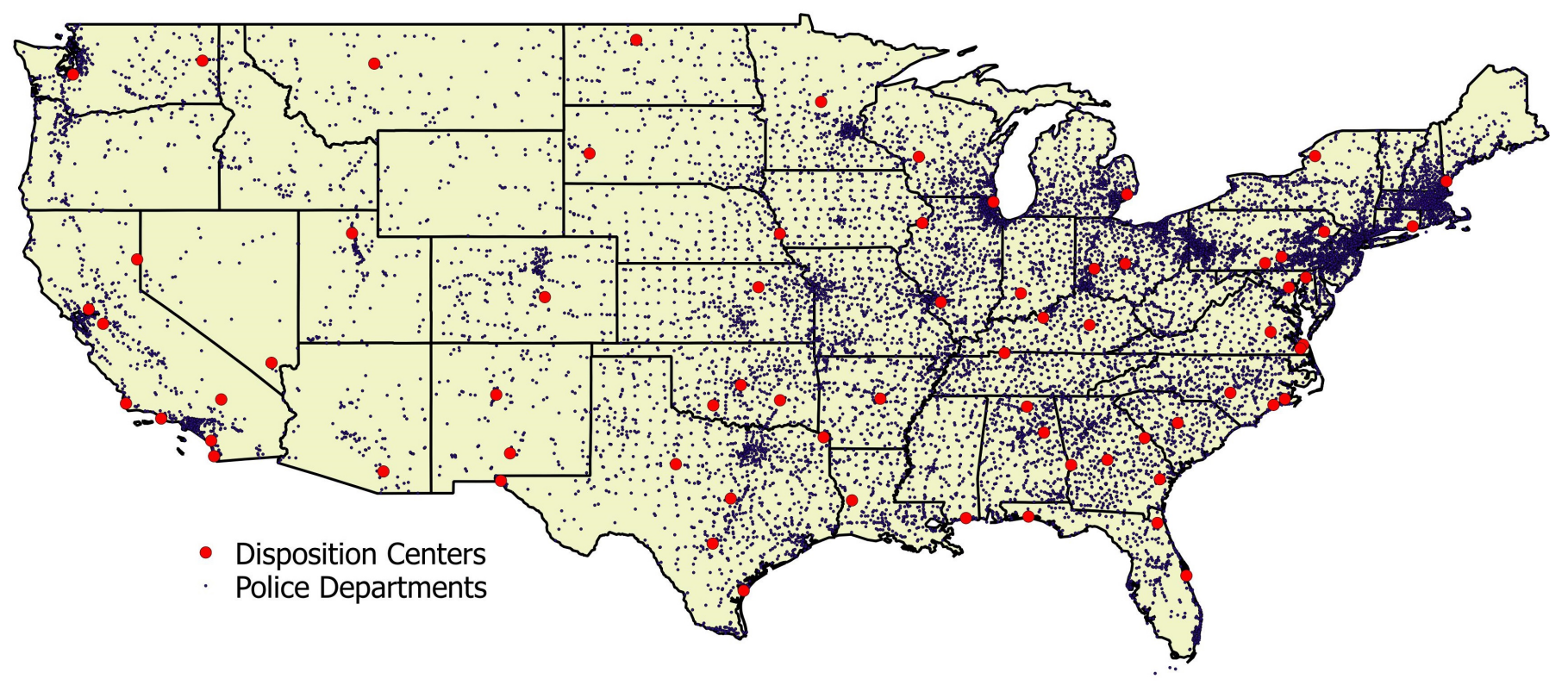

Figure 2: Disposition centers and Local Enforcement Agencies in continental US 


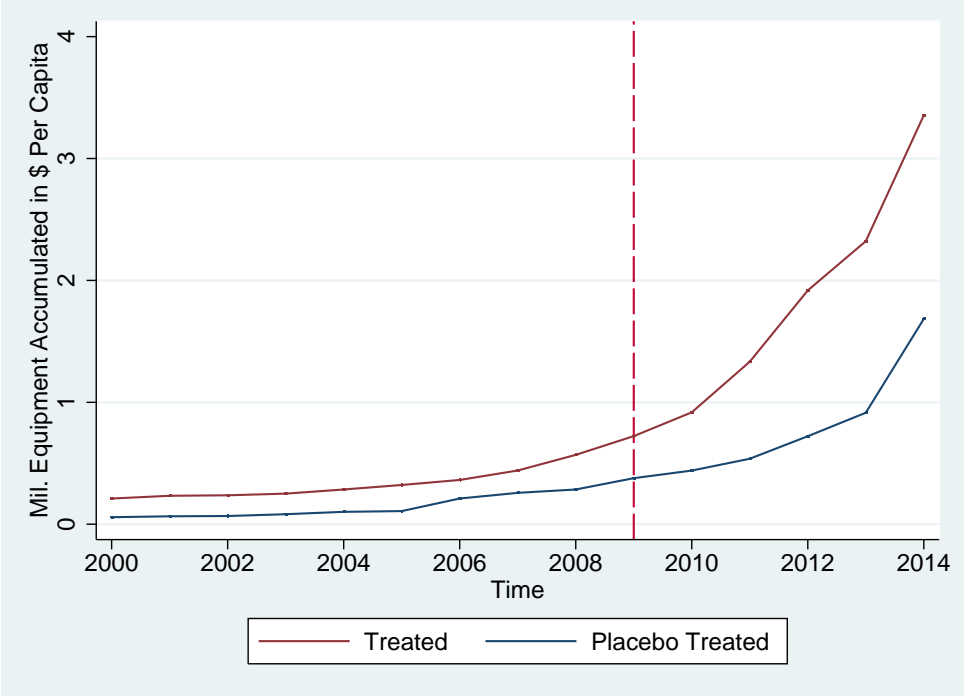

Figure 3: Time series of the stock of military equipment in $\$$ per capita. Blue line for police departments that are at most at $20 \mathrm{Km}$ for a disposition center. Red Line for police departments that are at most at $20 \mathrm{Km}$ from a military base that is not a police department

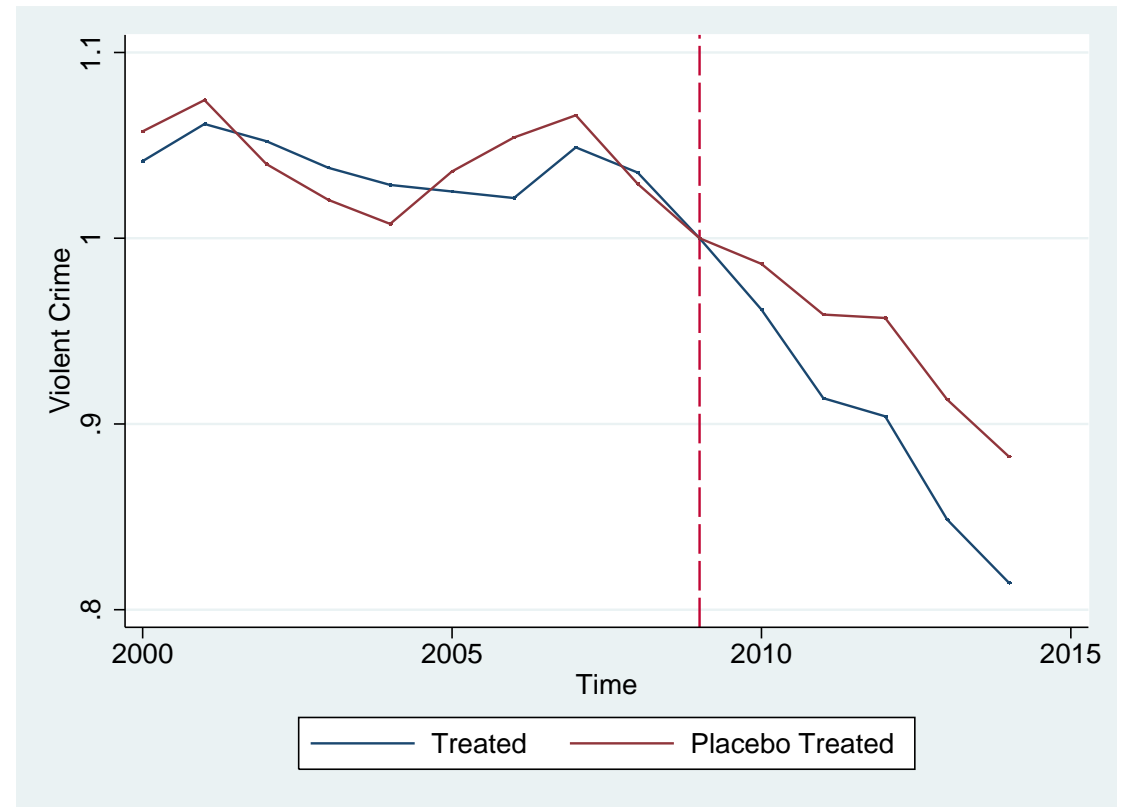

Figure 4: Violent crime rates of police departments close to disposition centers (treated in blue) and police departments close to military bases that are not disposition centers (placebo treated in red). Violent crime rates are normalized to 1 in 2009. 


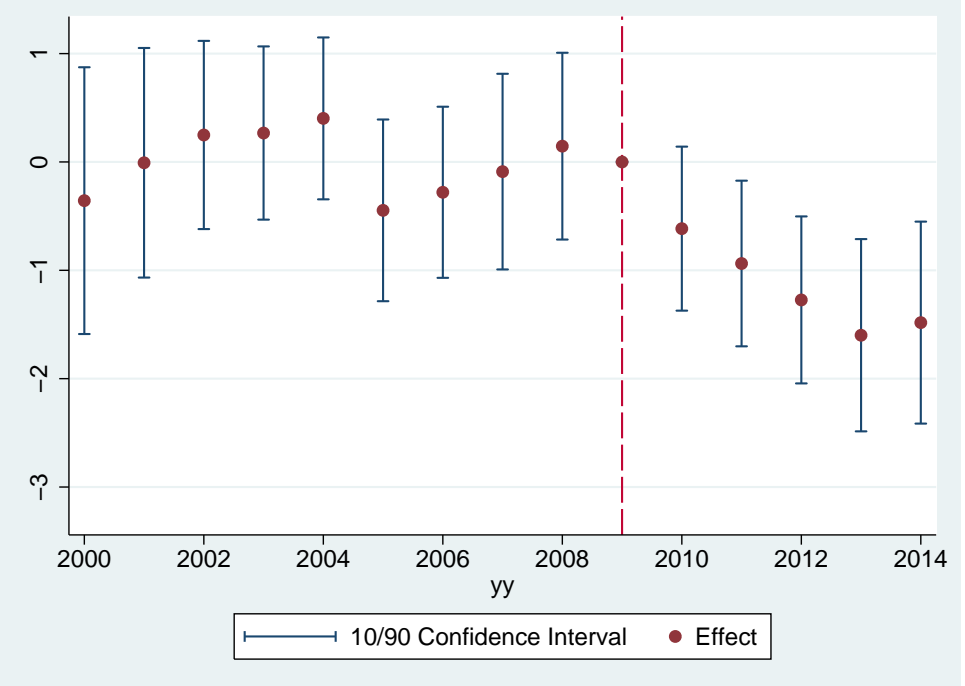

Figure 5: The time series of the reduced form effects $\sigma_{1, t}$ (2009 as comparison year)

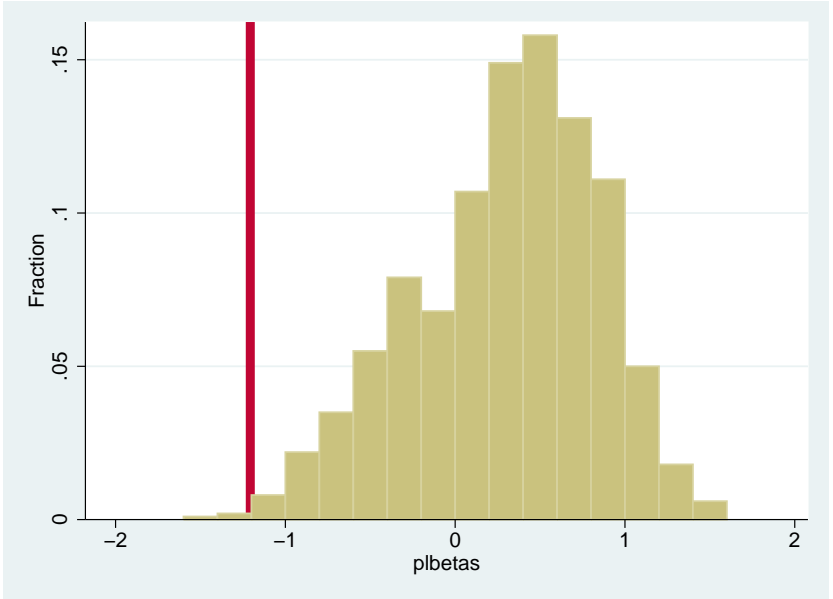

Figure 6: Distribution of the $\sigma_{1}$ of the fake reduced form. With the red line the reduced form with the "real" disposition centers 


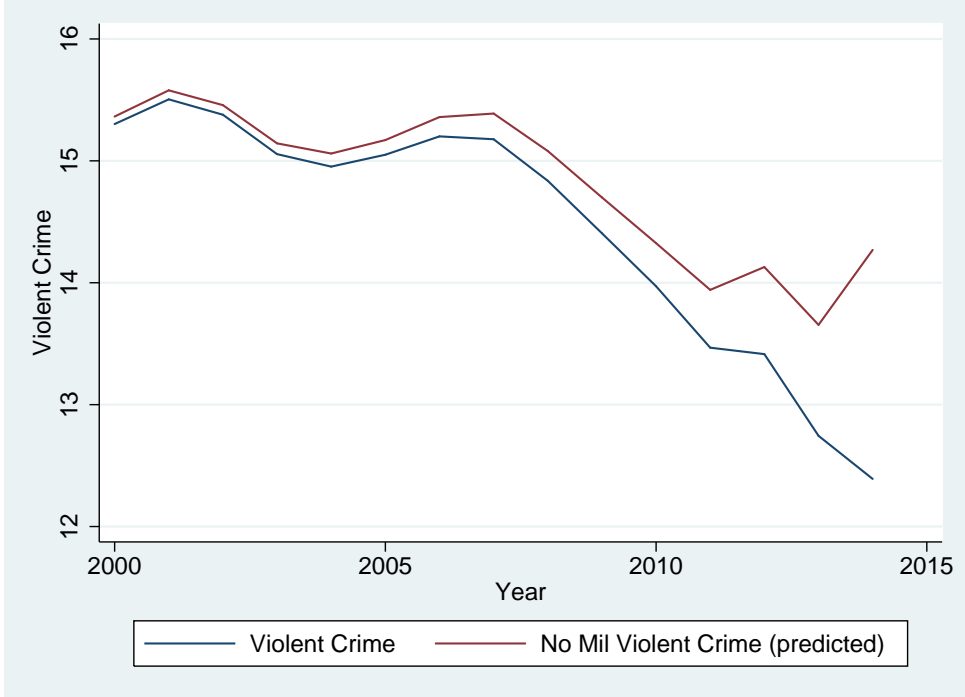

Figure 7: Violent crime rate (blue) and predicted violent crime rate if there was no militarization

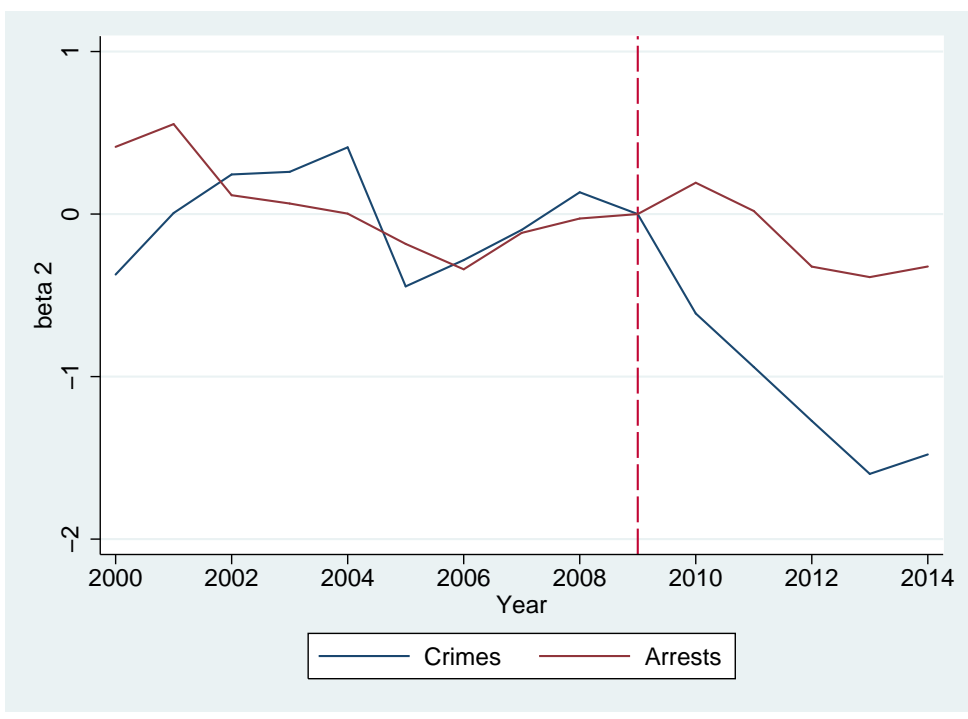

Figure 8: The time series of the reduced form effects $\beta_{1, t}$ (2009 as comparison year) 
Table 1: First Stage: Closeness to Disposition Centers and the Militarization of police departments

\begin{tabular}{lcccccc}
\hline & $<20 \mathrm{Km}$ & $<40 \mathrm{Km}$ & Dist & $\ln ($ Dist. & Num. 50Km & Num. 100Km \\
\hline$\beta_{1}$ & $0.863^{* * *}$ & $0.444^{* *}$ & -0.00163 & $-0.254^{* *}$ & $0.462^{* * *}$ & $0.396^{* * *}$ \\
& $(0.287)$ & $(0.192)$ & $(0.00135)$ & $(0.0984)$ & $(0.152)$ & $(0.130)$ \\
\hline Observations & 98846 & 98846 & 98846 & 98846 & 98846 & 98846 \\
F-stat & 29.46 & 13.63 & 5.29 & 21.69 & 23.65 & 33.69 \\
\hline
\end{tabular}

Note: The table reports the OLS estimates of the first stage $\beta_{1}$ and clustered standard errors at the state*year level (in brackets). The sample includes all police departments yearly data from 2007 to 2014 . In the first 2 columns a police department is defined as close if situated at less than $20 \mathrm{~km}$, for column 1, and $40 \mathrm{Km}$, for column 2 , from a disposition center. In column 3 I use the distance in $\mathrm{Km}$ and in column 4 the logarithmic distance in $\mathrm{Km}$ from the closest disposition centers. In column 5 and $6 \mathrm{I}$ use the number of disposition centers in a radius of $50 \mathrm{Km}$ and $100 \mathrm{Km}$ as a measure of closeness. All regressions include police departments fixed effects, year fixed effects and year $_{t} *$ closeness (militarybase) and are weighted by population. ${ }^{*} p$-value $<0.10$, ** $p$-value $<0.05$, *** p-value $<0.01$

Table 2: Second Stage: Militarization on Violent Crime

\begin{tabular}{lccccc}
\hline & OLS & OLS FE & IV & IV & Reduced Form \\
& Violent Cr. & Violent Cr. & Violent Cr. & $\ln$ (Violent Cr.) & \begin{tabular}{c} 
Violent Cr. \\
\hline Militarization per Capita
\end{tabular} \\
& 0.00341 & 0.00121 & $-1.399^{* *}$ & $-0.0636^{* *}$ & \\
& $(0.00476)$ & $(0.00192)$ & $(0.553)$ & $(0.0273)$ & $-1.207^{* * *}$ \\
Eqp. X 1(disp $<20 \mathrm{Km})$ & & & & & $(0.238)$ \\
\hline Observations & & & & 95216 & 99570 \\
Year FE & 99879 & 99570 & 99570 & Yes & Yes \\
Police Dep. FE & Yes & Yes & Yes & Yes & Yes \\
1(Milbase $<20 \mathrm{Km}) *$ Year & No & Yes & Yes & Yes & Yes \\
F-stat & No & No & Yes & 28.45 & \\
\hline
\end{tabular}

Note: In column (4) the dependent variable is the log of the violent crime rate. In all the other columns the dependent variable is the violent crime rate per 1000 inhabitants. The sample includes all police departments yearly data from 2007 to 2014. The first 2 columns report the OLS estimates of militarization per capita on violent crime rate. Column 3 reports the first stage. Columns 4 to 5 report the IV second stage estimates. Finally Column 65 reports the reduced form evidence of the treatment status. In all columns clustered standard errors at the state*year level are reported in brackets. Regressions are weighted by population. * $p$-value $<0.10,{ }^{* *}$-value $<0.05$, *** p-value $<0.01$ 
Table 3: Comparing Levels of Predetermined Observables

\begin{tabular}{lccccc}
\hline \hline Variable & $\begin{array}{c}\text { Treated } \\
(\mathbf{1})\end{array}$ & $\begin{array}{c}\text { Placebo } \\
(\mathbf{2})\end{array}$ & $\begin{array}{c}\text { Other } \\
(\mathbf{3})\end{array}$ & $\begin{array}{c}\text { Difference } \\
(\mathbf{1})-(\mathbf{2})\end{array}$ & $\begin{array}{c}\text { Difference } \\
(\mathbf{1})-(\mathbf{3})\end{array}$ \\
\hline Sheriff Department (2009) & 0.15 & 0.12 & 0.33 & 0.03 & $-0.18^{\star \star \star}$ \\
Municipal Level (2009) & 0.73 & 0.71 & 0.56 & 0.02 & $0.17^{\star \star \star}$ \\
Civilian Employees per Capita (2009) & 0.89 & 0.96 & 0.88 & -0.07 & 0.01 \\
Officers per Capita (2009) & 1.84 & 2.58 & 1.99 & $-0.74^{\star \star}$ & -0.15 \\
Area (2009) & 316.11 & 257.99 & 502.98 & 58.12 & $-186.87^{\star}$ \\
Juvenile Age (2009) & 17.17 & 16.59 & 16.01 & 0.57 & $1.16^{\star \star \star}$ \\
Violent Crime Rate (2009) & 18.12 & 14.94 & 13.24 & 3.17 & $4.87^{\star \star \star}$ \\
Property Crime Rate (2009) & 36.89 & 31.33 & 29.07 & 5.56 & $7.82^{\star \star \star}$ \\
Population & 60357 & 53518 & 19422 & 6839 & $40935^{\star \star \star}$ \\
\hline \hline \% Male (2000) & 49.31 & 48.75 & 49.10 & 0.56 & 0.21 \\
\% Latino (2000) & 14.90 & 13.85 & 12.34 & 1.05 & 2.56 \\
\% Mexican (2000) & 9.92 & 5.33 & 7.67 & 4.58 & 2.25 \\
\% Black (2000) & 14.19 & 18.89 & 10.69 & -4.71 & 3.50 \\
Criminal Active Population (15-35) (2000) & 29.49 & 30.82 & 27.58 & -1.33 & $1.91^{\star \star \star}$ \\
Unemployment Rate (2000) & 3.85 & 3.98 & 4.08 & -0.14 & -0.23 \\
\% Less Than High-School (2000) & 17.12 & 17.78 & 20.08 & -0.66 & $-2.96^{\star \star}$ \\
Republican Governor (2000) & 0.73 & 0.61 & 0.61 & 0.12 & 0.12 \\
Republican Governor (2005) & 0.58 & 0.71 & 0.62 & -0.13 & -0.04 \\
Governor Election (2008-2009) & 0.21 & 0.23 & 0.16 & -0.02 & 0.04 \\
Governor Election (2013-2014) & 0.86 & 0.83 & 0.84 & 0.03 & 0.02 \\
Participation Presidential Election (2004) & 0.59 & 0.49 & 0.60 & 0.09 & -0.01 \\
Participation Presidential Election (2008) & 0.65 & 0.54 & 0.64 & 0.11 & 0.01 \\
\hline
\end{tabular}

Note: This table shows some predetermined observables for police departments less than $20 \mathrm{Km}$ from a disposition center (Treated), police departments less than $20 \mathrm{Km}$ from a military base that is not a disposition center (Placebo Treated) and all the other police departments more than $20 \mathrm{Km}$ from a military base (Other). The last two columns tests it tests if there are difference between trated and placebo police departments and betweeen treated and the other police departments. $\star 10 \% \star \star 5 \%$ $\star \star \star 1 \%$. The first 9 variables (above the doble horizontal line) are at the police department level in the year 2009. The other variables are at the county level. Demographic variables are from the 2000 Census. 
Table 4: Comparing Changes between 2006 and 2009

\begin{tabular}{lccccc}
\hline \hline Variable & $\begin{array}{c}\text { Treated } \\
(\mathbf{1})\end{array}$ & $\begin{array}{c}\text { Placebo } \\
(\mathbf{2})\end{array}$ & $\begin{array}{c}\text { Other } \\
\mathbf{( 3 )}\end{array}$ & $\begin{array}{c}\text { Difference } \\
(\mathbf{1})-(\mathbf{2})\end{array}$ & $\begin{array}{c}\text { Difference } \\
(\mathbf{1})-(\mathbf{3})\end{array}$ \\
\hline Violent Crime & -0.595 & -0.851 & -0.817 & 0.256 & 0.223 \\
Property Crime & -3.798 & -3.699 & -2.961 & -0.099 & -0.837 \\
Total Crime & -4.393 & -4.550 & -3.778 & 0.158 & -0.615 \\
Murder & -0.008 & -0.016 & -0.006 & $0.008^{\star}$ & -0.002 \\
Rape & -0.015 & -0.035 & -0.018 & 0.020 & 0.004 \\
Robbery & -0.160 & -0.335 & -0.130 & $0.175^{\star}$ & -0.029 \\
Assault & -0.412 & -0.465 & -0.662 & 0.052 & 0.250 \\
Burglary & 0.025 & -0.379 & -0.131 & 0.405 & 0.157 \\
Larceny & -1.328 & -1.230 & -1.649 & -0.098 & 0.321 \\
Motor Vchl. Thefth & -2.495 & -2.090 & -1.181 & -0.405 & $-1.315^{\star \star}$ \\
Officer Killed & -0.000 & 0.032 & -0.001 & -0.032 & 0.001 \\
Officer Assaulted & -0.086 & -4.068 & -2.039 & 3.982 & 1.953 \\
Justifiable Homicide & 0.106 & 0.010 & -0.009 & 0.096 & $0.115^{\star \star}$ \\
Fatal Encounters & 0.072 & -0.018 & 0.011 & 0.089 & $0.061^{\star}$ \\
\hline
\end{tabular}

Note: This table shows the change of various outcome variables between 2009 and 2006 for police departments less than $20 \mathrm{Km}$ from a disposition center (Treated), police departments less than $20 \mathrm{Km}$ from a military base that is not a disposition center (Placebo Treated) and all the other police departments more than $20 \mathrm{Km}$ from a military base (Other). The last two columns tests it tests if these changes are different between trated and placebo police departments and betweeen treated and the other police departments. $\star 10 \% \star \star 5 \% \star \star \star 1 \%$

Table 5: Second Stage: Robustness to Different Instruments

\begin{tabular}{lcccccc}
\hline & $(1)$ & $(2)$ & $(3)$ & $(4)$ & $(5)$ & $(6)$ \\
& Baseline & $<40 \mathrm{Km}$ & Min & $\ln (\mathrm{Min})$ & Disp. 50Km & Disp. 100Km \\
\hline Militarization per Capita & $-1.399^{* *}$ & $-1.667^{* *}$ & -0.792 & $-1.053^{* *}$ & $-1.173^{* *}$ & $-0.792^{* *}$ \\
& $(0.553)$ & $(0.811)$ & $(0.804)$ & $(0.489)$ & $(0.511)$ & $(0.377)$ \\
\hline Observations & 99570 & 99570 & 99556 & 99556 & 99570 & 99570 \\
F-stat & 29.58 & 13.68 & 5.34 & 21.86 & 23.61 & 34.20 \\
\hline
\end{tabular}

Note: In all columns the dependent variable is the violent crime rate per 1000 inhabitants. The sample includes all police departments yearly data from 2007 to 2014 . The table reports IV estimates of $\theta_{1}$ and clustered standard errors at the state*year level in brackets. In the first 2 columns a police department is defined as close if situated at less than $20 \mathrm{~km}$, for column 1 , and $25 \mathrm{Km}$, for column 2 , from a disposition center. In column 3 I use the distance in $\mathrm{Km}$ and in column 4 the logarithmic distance in Km from the closest disposition centers. In column 5 and $6 \mathrm{I}$ use the number of disposition centers in a radius of $50 \mathrm{Km}$ and $100 \mathrm{Km}$ as a measure of closeness. All regressions include police department fixed effects, year fixed effects and $y_{\text {ear }} *$ closeness(militarybase) as inclueded instruments and are weighted by population. ${ }^{*} p$-value $<0.10,{ }^{* *} p$-value $<0.05,{ }^{* * *} p$-value $<0.01$ 
Table 6: Second Stage: Sample only includes police departments close to a military bases

\begin{tabular}{lccccc}
\hline & $(1)$ & $(2)$ & $(3)$ & $(4)$ & $(5)$ \\
& OLS & OLS FE & IV & LOG IV & RF \\
\hline Militarization per Capita & $-0.0146^{* * *}$ & 0.000290 & $-1.402^{* *}$ & $-0.0639^{* *}$ & \\
& $(0.00442)$ & $(0.00270)$ & $(0.552)$ & $(0.0273)$ & \\
Eqp. X 1(dist $<20 \mathrm{Km})$ & & & & & $-1.210^{* * *}$ \\
& & & & & $(0.237)$ \\
\hline Observations & 11431 & 11414 & 11414 & 11176 & 11414 \\
Year FE & Yes & Yes & Yes & Yes & Yes \\
Police Dep. FE & No & Yes & Yes & Yes & Yes \\
1(Milbase $<20 \mathrm{Km}) *$ Year & No & No & Yes & Yes & Yes \\
F-stat & & & 15.46 & 15.10 & \\
\hline
\end{tabular}

Note: In column (4) the dependent variable is the log of the violent crime rate. In all the other columns the dependent variable is the violent crime rate per 1000 inhabitants. The sample includes all police departments yearly data from 2007 to 2014. The first 2 columns report the OLS estimates of militarization per capita on violent crime rate. Columns 3 to 4 report the IV second stage estimates. Finally Column 5 reports the reduced form evidence of the treatment status. In all columns clustered standard errors at the state*year level are reported in brackets. Regressions are weighted by population. ${ }^{*} p$ value $<0.10,{ }^{* *} p$-value $<0.05,{ }^{* * *} p$-value $<0.01$ 
Table 7: Second Stage: Different Definition of Military Base

\begin{tabular}{lccccc}
\hline & \multicolumn{2}{c}{ All Bases } & & \multicolumn{2}{c}{ Not } \\
\cline { 2 - 3 } \cline { 5 - 6 } & $(1)$ & $(2)$ & & $(3)$ & $(4)$ \\
& IV & LOG IV & & IV & LOG IV \\
\hline Militarization per Capita & $-1.375^{* * *}-0.0550^{* *}$ & $-1.612^{* *}$ & $-0.0632^{* *}$ \\
& $(0.526)$ & $(0.0260)$ & & $(0.628)$ & $(0.0274)$ \\
\hline Observations & 99570 & 95216 & & 99570 & 95216 \\
F-stat & 26.76 & 25.79 & & 28.00 & 27.02 \\
\hline
\end{tabular}

Note: In column (2) and (4) the dependent variable is the log of the violent crime rate. In all the other columns the dependent variable is the violent crime rate per 1000 inhabitants. The sample includes all police departments yearly data from 2007 to 2014. The difference with the main results is which military bases are selected as control. In the first 2 the closeness to all military bases, even closed ones are used as a included istrument. Columns 3 to 4 all military bases that are not closed are instead used as included instruments. In all columns clustered standard errors at the state*year level are reported in brackets. Regressions are weighted by population. ${ }^{*} p$-value $<0.10,{ }^{* *} p$ value $<0.05,{ }^{* * *}$ p-value $<0.01$

Table 8: Second Stage: Droping big cities and not Weighting by Population

\begin{tabular}{lccccc}
\hline & \multicolumn{2}{c}{ Drop Big Cities } & & \multicolumn{2}{c}{ Not Weighted Regression } \\
\cline { 2 - 3 } \cline { 5 - 6 } & $(1)$ & $(2)$ & & $(3)$ & $(4)$ \\
& Pop $<500 \mathrm{~K}$ & Pop $<250 \mathrm{~K}$ & & Pop $>5 \mathrm{~K}$ & Pop $>10 \mathrm{~K}$ \\
\hline Militarization per Capita & $-0.754^{* *}$ & $-0.511^{* *}$ & & $-0.174^{*}$ & $-0.623^{*}$ \\
& $(0.352)$ & $(0.232)$ & & $(0.0987)$ & $(0.326)$ \\
\hline Observations & 99186 & 98694 & & 58017 & 40064 \\
F-stat & 37.71 & 48.81 & & 68.68 & 23.81 \\
\hline
\end{tabular}

Note: This table reports the IV estimates of the effect of militarization on violent crime. In column (1) and (2) police departments with more than 500000 and 250000 inhabitants are dropped repectevely. Column (3) and (4) report the results without weighting for population and dropping police departments with less tahn 5000 and 10000 inhabitants respectively. The sample yearly data from 2007 to 2014 at the police department level. In all columns clustered standard errors at the state*year level are reported in brackets. ${ }^{*} p$ value $<0.10,{ }^{* *} p$-value $<0.05, * * * p$-value $<0.01$ 
Table 9: Displacement Effects

\begin{tabular}{lcccc}
\hline & $(1)$ & $(2)$ & $(3)$ & $(4)$ \\
& Baseline & CZ mil & Baseline & CZ mil \\
\hline Militarization per Capita & $-1.399^{* *}$ & $-1.558^{* *}$ & $-0.0636^{* *}$ & $-0.0718^{* *}$ \\
& $(0.553)$ & $(0.696)$ & $(0.0273)$ & $(0.0348)$ \\
& & & & \\
CZ Militarization per Capita & & $0.499^{*}$ & & $0.0259^{* *}$ \\
& & $(0.267)$ & & $(0.0132)$ \\
\hline Observations & 99570 & 99540 & 95216 & 95190 \\
F-stat & 29.58 & 11.48 & 28.45 & 11.04 \\
Pvalue Underindentification & .003 & .008 & .003 & .008 \\
F-stat 1st Stage mil & & 20.89 & & 20.73 \\
F-stat 1st Stage CZmil & & 110.33 & & 110.11 \\
Corr(instr.,CZ instr.) & & .064 & & .064 \\
\hline
\end{tabular}

Note: In columns (1) and (2) the dependent variable is the violent crime rate per 1000 inhabitants, in columns (3) and (4) the dependent variable is the log of this violent crime rate. The sample includes all police departments yearly data from 2007 to 2014 . The table reports IV estimates of $\beta_{1}, \beta_{2}$ and clustered standard errors at the state*year level in brackets. All regressions include police department fixed effects, year fixed effects and year $t_{t} * 1$ (militarybase $\left.<20 \mathrm{~km}\right)$. Regressions are weighted by population. * ${ }^{*}$-value $<0.10$, ** $p$-value $<0.05$, *** $p$-value $<0.01$ 
Table 10: Arrests

\begin{tabular}{lccccc}
\hline & $(1)$ & $(2)$ & $(3)$ & $(4)$ & $(5)$ \\
& OLS & OLS FE & IV & LOG IV & RF \\
\hline Militarization per Capita & $0.00543^{* *}$ & 0.000612 & -0.438 & -0.0581 & \\
& $(0.00270)$ & $(0.00137)$ & $(0.332)$ & $(0.0482)$ & \\
Eqp. X 1(disp $<20 \mathrm{Km})$ & & & & & $-0.262^{*}$ \\
& & & & & $(0.154)$ \\
\hline Observations & 94353 & 94087 & 94087 & 87181 & 94087 \\
Year FE & Yes & Yes & Yes & Yes & Yes \\
Police Dep. FE & No & Yes & Yes & Yes & Yes \\
1(Milbase $<20 \mathrm{Km}) *$ Year & No & No & Yes & Yes & Yes \\
F-stat & & & 14.71 & 13.91 & \\
\hline
\end{tabular}

Note: In column (2) the dependent variable is the log of the arrests due to violent crimes per 1000 inhabitants. In all the other columns the dependent variable is the number of arrests due to violent crimes per 1000 inhabitants. The sample includes all police departments yearly data from 2007 to 2014 . In all columns clustered standard errors at the state*year level are reported in brackets. Regressions are weighted by population. ${ }^{*} p$-value $<0.10,{ }^{* *} p$ value $<0.05$, *** $p$-value $<0.01$

Table 11: Employees Police

\begin{tabular}{lccc}
\hline & $(1)$ & $(2)$ & $(3)$ \\
& Employees & Policemen & Civilians \\
\hline Militarization per Capita & 0.0101 & 0.0201 & -0.0100 \\
& $(0.0325)$ & $(0.0203)$ & $(0.0317)$ \\
\hline Observations & 118626 & 118626 & 118626 \\
F-stat & 39.54 & 39.54 & 39.54 \\
\hline
\end{tabular}

Note: The table reports instrumental variable estimates. In all columns clustered standard errors at the state*year level are reported in brackets. Regressions are weighted by population. The sample includes all police departments yearly data from 2007 to 2014. The dependent variables the are number of total employees, policemen and civilian employees every 1000 citizens. * p-value $<0.10$, ** p-value $<0.05$, *** $p$-value $<0.01$ 
Table 12: Police Safety and Police Killings

\begin{tabular}{lcccc}
\hline & $(1)$ & $(2)$ & $(3)$ & $(4)$ \\
& Officers & Officers & Police & Police \\
& Killed & Assaulted & Killings & Killings (Blacks) \\
\hline Militarization per Capita & 0.0250 & 4.529 & $0.0782^{* *}$ & 0.0136 \\
& $(0.0228)$ & $(4.195)$ & $(0.0391)$ & $(0.0147)$ \\
\hline Observations & 21156 & 21156 & 130536 & 130536 \\
Year FE & Yes & Yes & Yes & Yes \\
Police Dep. FE & Yes & Yes & Yes & Yes \\
1(Milbase $<20 \mathrm{Km}) *$ Year & Yes & Yes & Yes & Yes \\
F-stat & 18.44 & 18.44 & 43.45 & 43.45 \\
\hline
\end{tabular}

Note: The table reports instrumental variable estimates. In all columns clustered standard errors at the state*year level are reported in brackets. Regressions are weighted by population. The sample includes all police departments yearly data from 2007 to 2014. The dependent variables are the number of officers killed, officers assaulted, police killings and police killings of black people every 100000 citizens. ${ }^{*} p$-value $<0.10$, ** $p$-value $<0.05$, *** p-value $<0.01$ 